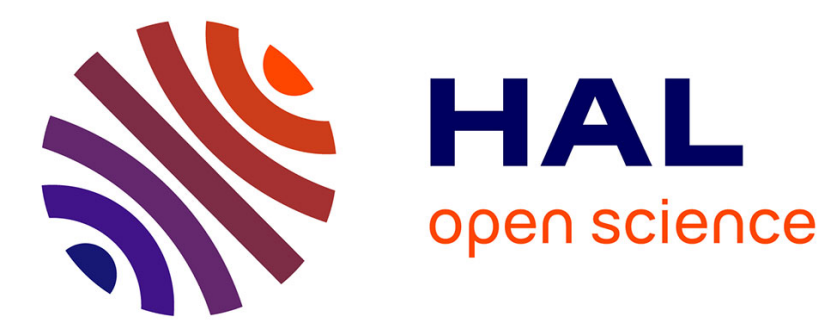

\title{
Gall-Inducing Parasites: Convergent and Conserved Strategies of Plant Manipulation by Insects and Nematodes
}

Bruno Favery, Géraldine Dubreuil, Ming-Shun Chen, David Giron, Pierre Abad

\section{To cite this version:}

Bruno Favery, Géraldine Dubreuil, Ming-Shun Chen, David Giron, Pierre Abad. Gall-Inducing Parasites: Convergent and Conserved Strategies of Plant Manipulation by Insects and Nematodes. Annual Review of Phytopathology, 2020, 58, pp.1-22. 10.1146/annurev-phyto-010820-012722 . hal-03025822

\section{HAL Id: hal-03025822 \\ https://hal.science/hal-03025822}

Submitted on 3 Dec 2020

HAL is a multi-disciplinary open access archive for the deposit and dissemination of scientific research documents, whether they are published or not. The documents may come from teaching and research institutions in France or abroad, or from public or private research centers.
L'archive ouverte pluridisciplinaire HAL, est destinée au dépôt et à la diffusion de documents scientifiques de niveau recherche, publiés ou non, émanant des établissements d'enseignement et de recherche français ou étrangers, des laboratoires publics ou privés. 


\title{
Gall-Inducing Parasites: Convergent and Conserved Strategies of Plant Manipulation by Insects and Nematodes
}

\author{
Bruno Favery, ${ }^{1, *}$ Géraldine Dubreuil,,${ }^{2, *}$ Ming-Shun Chen, ${ }^{3}$ David Giron, ${ }^{2}$ and \\ Pierre $\mathrm{Abad}^{1}$ \\ ${ }^{1}$ INRAE, CNRS, Université Côte d'Azur, ISA, F-06600 Sophia-Antipolis, France; email: \\ pierre.abad@inra.fr
}

${ }^{2}$ Institut de Recherche sur la Biologie de l'Insecte, CNRS, Université de Tours, UMR 7261, 37200 Tours, France; email: david.giron@univ-tours.fr

${ }^{3}$ USDA-ARS and Department of Entomology, Kansas State University, Manhattan, Kansas 66056, USA

*These authors contributed equally to this work; ${ }^{\dagger}$ Joint corresponding authors.

\section{Keywords}

galling insects, leaf-mining insects, plant-parasitic nematodes, feeding cells, nutritive cells, effectors

\begin{abstract}
Gall-inducing insects and nematodes engage in sophisticated interactions with their host plants. These parasites can induce major morphological and physiological changes in host roots, leaves, and other tissues. Sedentary endoparasitic nematodes, root-knot and cyst nematodes in particular, as well as gall-inducing and leaf-mining insects manipulate plant development to form unique organs that provide them with food from feeding cells. Sometimes, infected tissues may undergo a developmental switch resulting in the formation of aberrant and spectacular structures (clubs or galls). We describe here the complex interactions between these plant-reprogramming sedentary endoparasites and their infected hosts, focusing on similarities between strategies of plant manipulation. We highlight progress in our understanding of the host plant response to infection and focus on the nematode and insect molecules secreted in planta. We suggest that looking at similarities may identify convergent and conserved strategies and shed light on the promise they
\end{abstract}


hold for the development of new management strategies in agriculture and forestry.

\section{INTRODUCTION}

Parasites account for a large proportion of living species. They benefit from nutritional resources at the expense of the host organism, with detrimental effects on host survival, growth, and reproduction. Parasitism has evolved independently on multiple occasions in many different taxonomic groups. In insects, several hundred independent transitions to parasitism have occurred during the course of evolution (139). The same is true for nematodes, the parasitic species of which are derived from several independent transitions to parasitism (135). Despite their diverse origins, all these different lineages have been confronted with similar issues concerning host-to-host transmission, host invasion, survival within the host, and the sustainable exploitation of host resources, and this has led to the development of similar weapons and strategies in different species (58). Selection has forced different lineages to converge toward the few host-parasite combinations that are actually viable and has optimized their fitness (104).

Plant parasites include microorganisms (bacteria, fungi, oomycetes, protozoa, phytoplasmas, viruses, and nematodes), other plants, and some herbivores (arthropods). Many plant-parasitic nematodes and insects are ectoparasites, but some live within plant tissues (or protected between the leaf sheaths) and feed internally. These 'endoparasites' include a number of sedentary insect and nematode species with intricate interactions that involve hijacking of plant cellular machinery and development, benefiting the parasites at the expense of the plant's growth and reproduction. The confined plant environment provides these sedentary plant-reprogramming insects and nematodes with a similar ecological setting and facilitate intimate and close interactions between independent genomes. This leads to molecular cross-talk between parasites and plants resulting in their ability to manipulate host plant development, causing complex tissue reorganization for their own benefit, which sometimes results in the formation of new plant organs within which they feed and grow $(1,74,117,121)$. These induced spectacular morphological and physiological alterations to host-plant tissues have become emblematic examples of plant manipulation $(47,54)$. Specialist feeding behaviors provides the sedentary endoparasites with an adaptive advantage over external modes of feeding by providing the parasites with access to the most nutritional tissues while allowing them to evade the principal defensive compounds produced by the plant (119). 
The diversity of plant responses and putative mechanisms involved suggests that these interactions probably involve more than just one or a few processes. Nevertheless, the available genomic resources, high-performance analytical chemistry tools, and comparisons between systems have suggested that some aspects of host plant manipulation are common to plantreprogramming insects and nematodes. These similarities between insects and nematodes that share a common endophytic and sedentary lifestyle may highlight a convergence of evolutionary strategies and may identify key molecular mechanisms that are involved during plant manipulation.

In this review, we discuss what is currently known about the convergent and conserved strategies of these sedentary and endoparasitic plant-reprogrammers focusing on insects and nematodes species for which significant datasets are currently available. Sedentary endoparasitic cyst nematodes (CNs; Globodera and Heterodera spp.) and root-knot nematodes (RKNs; Meloidogyne spp.) are the most widely studied plant-parasitic nematodes because of their economic importance (73) and the complexity of the nematode-induced transformation of root cells into nematode feeding cells (Figure 1) (1,11,117). Gall-inducing insects also remodel the content of cells and the structure of plant tissues at their feeding sites, and many induce the development of nutritive tissues (63) (Figure 2). Leaf-mining insects also reprogram the development of their host plants, albeit on a smaller scale, by manipulating plant tissues to delay senescence and improve their nutritional quality (75). While molecular data are scarce compared to RKNs and CNs, few insect species start to emerge as model systems for plant manipulation such as the Hessian Fly (cecidomyiid), oak gall wasps (cynipids) and microlepidoptera (gracillarids).

We first review and compare the functional mechanisms underlying the formation of feeding structures induced by gall-inducing/leaf-mining insects and root-knot/cyst nematodes. We then compare effectors for plant manipulation in insects and nematodes. Finally, as some reprogramming species are also important pests, we explore the potential benefits of this knowledge for agriculture and forestry.

\section{ALTERATION OF PLANT MORPHOLOGY AND PHYSIOLOGY}

During their long and intimate association with their hosts, plant-reprogramming insects and nematodes redirect normal plant metabolism and physiology toward the production of specialist 
feeding structures, e.g., nutritive cells or feeding cells, thereby robbing the plant of much-needed resources $(47,54,119)$. These alterations increase the nutritional value of the plant tissues consumed and improve the invaders' access to nutrients.

\section{Common Features of Feeding and Nutritive Cells}

The feeding systems induced have a number of structural and functional features in common, but their ontogeny differs considerably. The degree of nutritive tissue differentiation also differs between plant-reprogramming parasites, with greater differentiation observed for parasites that actively consume the tissues (e.g., chewing cynipid wasps and Gracillaridae moths). Nutritive tissues may therefore be highly localized or more extensive. The development of additional tissues that surround the feeding cells completely or partially and protect the inducer from abiotic stresses and/or natural enemies also varies among species. Some parasites induce structures with nutritive inner tissues and complex protective outer tissues, whereas others form less sophisticated structures consisting entirely of nutritive tissues, as observed for grass gall midges such as the Hessian fly Mayetiola destructor (63). The manipulation of the plant by plantreprogramming parasites often results in a combination of cell division (hyperplasia) and growth (hypertrophy) $(47,54)$. Plant tissue differentiation may also involve changes in cell ultrastructure. Large amounts of data obtained by light, scanning, and transmission-electron microscopy have been reported $(15,63)$. The nutritive cells induced by galling insects and the feeding cells induced by nematodes (RKNs and CNs) have a dense cytoplasm, with large numbers of cellular organelles, including numerous mitochondria, plastids, ribosomes, a welldeveloped Golgi apparatus, and smooth endoplasmic reticulum, generally organized into swirls. Changes in the volume and shape of the nucleus have also been reported, together with cell wall modifications, in all nutritive tissues $(15,63,74)$. These changes reflect an increase in the metabolism of these cells, which constitute a metabolic sink within the plant, providing the parasites with food throughout their life cycle.

\section{Ontogeny of Nematode Feeding Cells and Nutritive Cells of Galling and Leaf-Mining Insects}

RKN and $\mathrm{CN}$ are obligate parasites. After hatching from their eggs in the soil, they seek out the root systems of host plants (22) and penetrate roots usually as microscopic vermiform secondstage juveniles (J2s). Once within the roots, the mobile $\mathrm{J} 2 \mathrm{~s}$ migrate between (RKNs) or within 
(CNs) cells to reach the vascular cylinder of the plant. Having reached the stele, the J2s select one (CNs) or several (RKNs) root vascular cells and induce their transformation into specialized nematode feeding cells, known as syncytia (for CNs) and giant cells (for RKNs) (Figure 1). These large, multinucleate, metabolically active cells serve as the permanent and only source of nutrients for the developing nematode, which becomes sedentary (57). Each RKN J2 triggers the development of five to seven giant cells, each containing as many as 100 enlarged, highly lobed nuclei resulting from several rounds of nuclear division without cytokinesis (1). The concomitant swelling and division of cortical cells around the nematode give rise to the knot-like root shape characteristic of Meloidogyne spp. infection (Figure 1). Cyst nematodes induce changes in the plant different from those caused by RKNs and galling insects. They induce the formation of a syncytium from an initial feeding cell that fuses with hundreds of neighboring cells, thereby causing root distension (15). Within this metabolically active feeding site, the walls between the neighboring cells partially dissolve, leading to protoplast fusion and progressive increases in syncytium size, such that the final structure may incorporate more than 200 cells. Ultimately, both syncytia and giant cells have enlarged endoreduplicated nuclei with large nucleoli (32).

The characteristics and ontogeny of nutritive tissues differ between families and species of gall-inducing insects, but the nutritive cells have features similar to those of RKN and CN feeding cells (Figure 1). They have endoreduplicated and hypertrophied nuclei and nucleoli, a dense cytoplasm, thin walls, and a well-developed vascular system involving numerous enlarged plasmodesmata $(47,119)$. Hessian fly larvae attack wheat seedlings at the base of the inner sheath, using their mandibles to puncture an epidermal cell. Two days later, the first ultrastructural changes are observed, with evidence of nuclear breakdown, cytoplasmic organelle destruction, and an increase in the number and size of vacuoles (63). The following day, the epidermal cells become the first nutritive cells (increase in the numbers of cellular organelles, numerous small vacuoles, and an irregularly shaped nucleus), followed by mesophyll cells. Changes in the shape and density of the cell nucleus and in the cell wall are observed shortly before the nutritive cells rupture and release their contents. The contents of the nutritive cells then pass into adjacent cells through compromised cell walls and plasmodesmata in a process resembling the feeding strategy of CNs. Food components from the ruptured plant cells are mixed with larval secretions before ingestion, and the larva consumes soluble proteins and sugars in a liquid form. In other galling-insect species, such as cynipid wasps, the ontogeny of nutritive 
cells more closely resembles that of RKNs, with the production of enlarged metabolically active nutritive cells. Oviposition on the meristematic tissue by the female triggers the gall initiation phase. The gall chamber is formed by cell differentiation, and a growth phase then occurs, in which cell elongation leads to gall expansion. The parenchyma cells are converted into nutritive cells as the larvae feed, and the number of layers of cells in the inner-gall tissue decreases during development because the larvae feed on them. During maturation, cell division stops, the galls lignify, and the larvae mature and pupate. In some leaf-mining insects, cell division at the edges of the mine causes the mine to swell because of the larvae triggering leaf cell hypertrophy and proliferation (hyperplasia) (59). In some situations, the mixture of a physical process (e.g., leaf tissue folding mediated by silk production by the insect) and this uncharacterized chemical process can lead to the formation of fully closed galls $(59,60)$ (Figure 2). Insect species capable of switching from a non-manipulating leaf-mining lifestyle to gall-inducing larval development provide exciting new opportunities to decipher the molecular mechanisms underlying plant manipulation and explore the evolutionary origins of these plant manipulators.

\section{Vascularization and Nutrient Delivery at Feeding Sites}

The induction of feeding/nutritive cells by parasites in the vascular parenchyma seems to have several benefits. The position of the initial feeding cell(s) close to the xylem and phloem ensures the close contact between the feeding site and the plant vascular system required for the provision of nutrients to the developing syncytium, giant cells, or nutritive cells (8). In nematodes, the cells targeted in the vascular tissue may also be more responsive to the parasiteinduced changes, as they are not entirely differentiated and may therefore be able to convert into other cell types more easily. Rearrangements of the host vascular system result in the giant cells being surrounded by a network of newly formed xylem and phloem cells (8). This network appears to be essential for nutrient delivery to these parasite-induced sinks. However, the roles of cortical or endodermal cells outside the vascular cylinder tissue have yet to be determined for the syncytia induced by CNs and the giant cells induced by RKNs. In insect-induced galls, the nutritive tissues are typically supplied by vascular tissues connected to the vascular system of the host plant (120). New sieve tubes (phloem elements) are usually formed below the inner surface of the gall, supplying and enveloping the nutritive tissue $(111,141)$. The intense vascularization of the surrounding tissues undoubtedly increases the access to nutrients of the feeding nematode/insect. Feeding sites also affect overall plant growth by disturbing the transport of 
water and nutrients to and from plant tissues. The plant vascular system may also be involved in managing waste products from endophytic parasites; for example, the hydrophilic inner surface of the galls formed by gall-forming aphids is composed of a reticular spongy layer of cells derived from the plant that absorbs and removes liquid waste (80).

The modified structures at feeding sites act as strong metabolic sinks and have intense metabolic activity, resulting in the upregulation of protein and/or sugar synthesis at the parasite feeding site. They improve parasite access to nutrients or the nutritional value of the plant tissues consumed $(8,14,57,72,119,150)$. The modulation of the nutritional content of feeding cells has been interpreted as an adaptation to circumvent the mismatch between the nutrient status of unmodified host-plant tissues and the requirements of the parasite. Changes in cell wall morphology and composition may help parasites to feed because the contents of the plant cell are broken down and move from cell to cell through the compromised cell walls (54). Parasites probably harvest the cell contents in the nutritive tissue through a combination of an increase in the permeability of plant cell walls, an enlargement of the plasmodesmata, the mechanical action of mouthparts, the high turgor pressure in the nutritive cells, and, possibly, the secretion and injection of proteases into cells (63).

\section{PLANT MANIPULATION: DEFENSE, HORMONES, AND CELL WALL}

The dramatic modifications of host cells induced by plant-manipulating insects and nematodes require an extensive reprogramming of plant gene expression. The formation of these unusual feeding structures has been explored at the transcriptomic level in various plant-nematode and plant manipulating-insect interactions $(20,21,47,88,111,121,122)$. Thousands of differentially expressed plant genes have been shown to be associated with colonization by galling insects and nematodes. Although it is difficult to make direct comparisons between differentially expressed genes in these interactions due to the absence of common hosts, the assignment of these genes to functional categories has highlighted the importance of modifications to plant defense responses $(55,105)$, hormone pathways $(50)$, the cell cycle (32), the cell wall and cytoskeleton organization $(15,47,78)$, developmental processes (122), and metabolic reprogramming $(111,121)$. The regulation of host gene expression by transcription factors, small noncoding RNAs and epigenetics remains poorly documented despite its importance (70). Here, we highlight the similarities between these plant reprogrammers in terms 
of the suppression of plant defenses, the manipulation of hormone balance, and changes to cell wall architecture at feeding sites.

\section{Recognition of Plant-Reprogramming Parasites and Defense Suppression}

In plants, immune responses to infection are triggered by the recognition of invasion by complementary systems. These systems first perceive pathogen-associated molecular patterns (PAMPs; e.g., fungal chitin or bacterial flagellin) and damage-associated molecular patterns (DAMPs) released by the disrupted plant tissues via molecular pattern recognition receptors (PRRs) (110). In cases of damage due to herbivores, the recognition process involves HAMPs (herbivory-associated molecular patterns) for insects and NAMPs (nematode-associated molecular pattern) for nematodes $(41,68)$. Approximately 20 HAMPs and/or elicitors have been identified, but no molecule has yet been identified in galling or leaf-mining insects, and only one such NAMP has been identified in nematodes $(41,110,118)$. This first NAMP to be identified is an evolutionarily conserved nematode pheromone, a glycolipid called ascaroside (ascr\#18) (91). The binding of HAMPs/DAMPs to PRRs triggers a set of broad-spectrum downstream defense responses known as pattern-triggered immunity (PTI). Early events in PTI signaling include the activation of mitogen-activated protein (MAP) kinases and reactive oxygen species (ROS) and phytohormone production, resulting in rapid changes in gene expression $(58,110)$. PTI-deficient Arabidopsis mutants have revealed the importance of PTI in immunity to RKNs and CNs. The Arabidopsis BAK1 receptor kinase, which is required for the function of most PRRs, and the leucine-rich repeat receptor-like kinase NILR1 were recently shown to be essential for PTI responses initiated by nematodes $(95,125)$. The perception of cell wall fragments (oligogalacturonides) by polygalacturonase-inhibiting proteins (PGIPs) acting as receptors has also been shown to be involved in triggering damage-associated responses to CNs (112).

Not only have plant-parasitic nematodes and insects developed strategies for extracting nutrients from their host plants, they also suppress the constitutive and induced defenses of their hosts. Transcriptomic analyses of plant-nematode and plant-insect interactions have highlighted changes in gene expression correlated with wound or defense responses $(42,88,111,113,122)$. For example, various class III peroxidase (PRX) genes are induced by gall midge and nematode infections in both susceptible and resistant wheat genotypes but to different extents and at different times $(78,115)$. Class III PRXs are involved in inducible defense mechanisms against gall-causing organisms. They probably act by regulating extracellular hydrogen peroxide levels 
and producing ROS (89). Interestingly, most defense-associated genes are repressed in galls and syncytia during infection. The WRKY family transcription factors, which are known to act downstream from several plant hormones in the activation of plant defenses, are generally repressed $(5,42)$. Repression of genes encoding pathogenesis-related (PR) proteins has also been reported(42).

\section{Manipulation of Hormone Balance}

Phytohormones, such as salicylic acid (SA), ethylene (ET), and jasmonic acid (JA), control various aspects of plant defense responses to plant-reprogramming insects and nematodes, whereas auxins and cytokinins (CKs) have been implicated in the ability of these parasites to control plant growth and development $(9,41,50,53,128,145)$. By controlling the phytohormonal balance, plant-reprogramming insects and nematodes successfully exploit the plant by suppressing its defenses while promoting the development of specialist feeding structures (41). Recent reviews have described the complexity of JA- and SA-dependent pathway regulation during galling caused by insects and nematodes, and the role of other phytohormones, such as gibberellin and abscisic acid (ABA), in regulating JA- or SA-dependent signaling (47, $50,54,82,99)$. It may be pointed out that studies are sometimes contradictory between RKN and $\mathrm{CN}$ infections, and between nematode and galling insects.

Many studies have focused on the effects of gall formation on the phytohormones auxin [mostly indole-3-acetic acid (IAA)] and CKs, and how plant-reprogramming insects and nematodes use phytohormone-mediated mechanisms to control their host plants $(50,54)$. Auxin accumulates in the galls induced by RKNs, suggesting a potentially crucial role for this hormone in the formation of feeding sites. Interestingly, auxin and related compounds have been detected in RKN secretions (34). Auxin transport is manipulated to favor nematode feeding-site formation $(50,82)$ through the differential expression of genes encoding proteins involved in auxin signaling following nematode infection (81). Gall-inducing insects can biosynthesize IAA from tryptophan at the initiation site, as demonstrated in Gnorimoschema gallaesolidaginis (Lepidoptera), the pteromalid wasp Trichilogaster acaciaelongifoliae, and the larvae of Eurosta solidaginis (Diptera) and the sawfly (Pontania spp.) (54). These studies suggested that gallinducing organisms provide additional IAA, helping the parasite to induce the formation of its feeding site. Transcriptomic analyses have shown that the expression of plant genes involved in auxin biosynthesis and transport and in auxin responses is modulated by insect galling $(64,111$, 
$113,142)$.

CKs also play an important role in plant development by promoting cell division and regulating cell differentiation. RKNs appear to secrete forms of CKs active in plants. The high levels of CKs found in giant cells suggest a crucial function for these hormones in their formation (96). The $\mathrm{CN}$ Heterodera schachtii also secretes CKs to promote syncytium formation (114). A fine-tuning of $\mathrm{CK}$ homeostasis is required for the formation of $\mathrm{CN}$ feeding sites, as $\mathrm{CKs}$ are required for syncytium development but are also involved in the induction of host defenses. CKs also play a key role in the cell cycle activation required for RKN gall formation (37). There is also increasing evidence to suggest that CKs may be involved in the strategy used by gall inducers and leaf miners to colonize and manipulate their host plants $(54,128)$. The larvae of $E$. solidaginis and T. acaciaelongifoliae contain much higher levels of CKs than the surrounding gall tissues, suggesting that the insect may be the source of the CKs (54). Gall tissues induced by the aphid Tetraneura nigriabdominalis contain high levels of CKs and auxin, which are thought to be produced by the aphid itself (123). The expression of wild grape genes involved in CK signaling is extensively modulated in the formation of galls induced by Phylloxera (111). Such CK-related genes are also differentially expressed in oak infected with the gall wasp Biorhiza pallida (64). Thus, genes involved in CK synthesis/degradation are repressed in galls, whereas genes involved in CK signaling are upregulated in the cup-shaped galls induced by members of the Cecidomyiidae in Litsea acuminata leaves (113). CKs also accumulate to high levels in mined tissues, despite low levels of plant CK-related gene expression. Very large amounts of CKs have also been found in many leaf-mining insects, including the leaf-mining moths Phyllonorycter mespilella and Phyllonorycter blancardella (Lepidoptera), and the production of these hormones by the insect may be linked to the presence of bacterial endosymbionts $(75,144$, 146).

The cross talk between the IAA/CK and JA pathways is generally negative, with high levels of IAA and CKs generally decreasing JA signaling and, thus, compromising the defense responses of plants to galling insects, nematodes, and leaf miners. A transcriptomic analysis of the giant cells induced by Meloidogyne graminicola in rice revealed a downregulation of JA biosynthesis pathways (71), and feeding by leaf-miner fly larvae activates SA-inducible genes, thereby probably also suppressing JA-mediated plant defenses (77). The suppression of JAmediated defenses is a strategy common to galling/leaf-mining insects and nematodes and allows 
the early stages of feeding-site formation to occur. In P. blancardella, leaf mining is also associated with the enhanced biosynthesis of JA precursors, minor alterations to the SA pathway, and clear inhibition of the ABA pathway (145). ABA plays a key role in senescence and in promoting abscission as a means of plant defense against sessile insects (86). It has been suggested that ABA concentrations influence gall formation processes (128). High concentrations of ABA have been detected in gall tissues during the feeding of Dryocosmus kuriphilus and Lipara lucens larvae. Following attacks by the gall-inducing leafhopper Cicadulina bipunctata, ABA levels are 10-30 times higher in susceptible maize plants than in control plants (126). Intriguingly, ABA levels are low in the galls induced by $G$. gallaesolidaginis on Solidago altissima stems (127). Similarly, attacks by larvae of the Hessian fly $M$. destructor lead to a decrease in ABA levels relative to unattacked controls in both wheat and rice (149). ABA can trigger plant defense responses, even acting independently of JA in some circumstances. Gall inducers may, therefore, actively manipulate ABA levels to prevent the induction of plant defense responses $(127,128,149)$.

Finally, other phytohormones may also trigger feeding-cell differentiation. A functional analysis of phytosulfokines (PSKs) in Arabidopsis, together with their receptor PSKR1, showed that the expression of the genes encoding these small signaling peptides was restricted to the cells surrounding the giant cells and that pskrl mutants displayed defects of giant cell expansion preventing RKN development (107). Furthermore, strigolactones, hormones known to play an important role in plant development, have also been implicated in the formation of giant cells and syncytia $(43,83)$.

\section{Changes in Cell Wall Architecture in Feeding Sites}

In the feeding tissues induced by plant-manipulating insects, cell wall fortification is inhibited and cell expansion is promoted, resulting in an accumulation of cells with thin walls, in susceptible hosts. The giant cells formed following nematode attack display an unusually high degree of isotropic growth. Individual giant cells can reach sizes 400 times greater than that of vascular parenchyma cells. This cell expansion requires a spatially and temporally synchronized process of plant cell wall extension, synthesis, and degradation. The $\mathrm{CN}$ syncytium is formed by partial dissolution of the cell walls of neighboring cells (15). Such modifications have been explored at the transcriptomic level in different interactions. The expression of a large number of wheat genes involved in cell wall metabolism is altered following $M$. destructor attacks. Genes 
encoding enzymes involved in cell wall loosening and degradation (including $\beta$-expansin, pectinesterase, polygalacturonase, and endo-1,4- $\beta$ glucanases) are generally upregulated in susceptible hosts, whereas genes encoding proteins involved in cell wall strengthening, such as enzymes involved in the synthesis of cell wall components (e.g., cellulose synthase), are upregulated in resistant plants $(78,88)$. For RKNs and CNs, several cell wall remodeling enzymes, such as expansin, xyloglucantransglycosylases, pectin acetylesterase, pectate lyase, polygalacturonases, and pectinesterases, are also upregulated in response to nematode invasion, resulting in the extensive modifications to cell wall architecture required for feeding-site formation $(15,42)$. Recent immunocytochemical studies have highlighted major biochemical changes in cell walls induced during nematode feeding-site formation $(2,18)$.

\section{EFFECTOR TOOLKIT FOR PLANT CELL REPROGRAMMING}

The molecular dialogue between plants and plant-reprogramming insects and nematodes involves HAMPs/NAMPs, as described above, and effectors. Effectors are molecules produced by the parasites, secreted in planta or injected into plant tissue, that have a direct role in $(a)$ the avoidance of plant defense responses, $(b)$ facilitating host invasion, and (c) reprogramming plant cells as feeding sites for the benefit of the invader $(49,54,65,97,129)$.

Nematode effectors are produced principally by the three esophageal salivary glands and are injected into plant cells through a hollow protrusive stylet. They are described as stylet-secreted effectors or stylet secretions. The activity of the esophageal gland cells appears to be developmentally regulated. The two subventral glands $(\mathrm{SvG})$ secrete effectors enabling the $\mathrm{J} 2$ to penetrate to the root and migrate within it. The proteins secreted during parasitism are produced by the SvGs and, particularly, by the dorsal gland (DG) $(101,140)$. Some effectors may also be produced by other secretory organs, such as the chemosensory amphids, or may be secreted directly through the nematode cuticle, as reported for macrophage migration inhibitory factors (MiMIFs) (148). Insect effectors originate from diverse sources either from the ovipositing mothers or her gall-inhabiting offspring. They are primarily produced in and secreted from salivary glands but may also be found in frass, eggs, on the body surface, and in other types of secretions from the larval gut or the venom glands of the ovipositing mother, (41, 118). Most studies on nematode or insect effectors have focused on proteins and peptides originating from saliva, but other secreted molecules, such as phytohormones, have also been shown to favor 
these interactions.

\section{Nematode and Galling-Insect Effector Repertoires}

Various approaches have been used to characterize nematode effector repertoires, including strategies based on monoclonal antibodies, proteomics, transcriptomics, and genomics $(65,97$, 129). Approximately 500 secreted proteins were identified in the $M$. incognita secretions from preparasitic J2s (10). Although the vast majority of these proteins are pioneers, i.e. displaying no significant sequence similarity to any protein in databases and with no known functional domains, several of these secreted proteins contained domains suggesting known functions and/or had sequences similar to those of plant proteins, which they may mimic. This is the case for the calreticulin (CRT) and 14-3-3- like proteins which are key component of the cell homeostasis. Redox proteins, such as thioredoxins, glutathione peroxidases, glutathione-Stransferases, and protein disulphide isomerase (PDI) and a transthyretin-like protein (TTL5), were identified as proteins secreted by RKNs $(10,136)$. In addition, approximately 30 proteins, including two profilins (PFNs), were predicted to interact with actin or microtubules (10). CRTs are also present in $\mathrm{CNs}$, but there is no evidence that they are used as effectors by these nematodes (12).

The content of the salivary glands (sialome) of the Hessian fly M. destructor, which represents the only complete analysis to date in galling-insects, seems to be poorer with only 46 proteins identified, including one salivary apyrase, one CRT, and one peroxiredoxin (PRX). These proteins may be involved in controlling the extracellular ATP, $\mathrm{Ca}^{2+}$, and $\mathrm{H}_{2} \mathrm{O}_{2}$ danger signals, thereby modulating key aspects of plant physiology relevant to gall induction (25). A follow-up study revealed that a protein highly abundant in Hessian fly larval salivary glands, the nucleoside diphosphate kinase (NDK), was indeed injected into host tissues during feeding (137). Apyrase activity levels are also higher in Calliandra brevipes galls than in non-galled tissues, suggesting a key role for this early signaling disruptor (together with other molecules) in the plant reprogramming induced by plant-manipulating insects (35). Interestingly, PRXs have been detected in the salivary secretions of several insects and have been shown to be required for successful M. incognita development (38).

\section{Contribution of Genomes and Their Expression to Effector Identification}

Advances in sequencing technologies have facilitated the identification of candidate effectors. 
The availability of complete genome sequences available for gall-inducing parasites such as RKNs (13), CNs $(27,45,92)$, and the Hessian fly (147) have considerably expanded the repertoire of these putative secreted effectors. Genome-wide searches based on the presence of the signal peptide returns in thousands of candidate genes for putative effector proteins in these species. In RKN and CN genome-wide transcriptomic analysis led to the identification of genes upregulated in planta and the comparison of specific tissues, such as salivary glands, and different stages of development helped narrow down the candidate effector repertoire $(3,4,25$, 94, 97, 118, 129). These effector proteins are generally found in only RKNs or CNs. Only a few are found in both types of nematode. Plant cell wall-degrading enzymes (PCWDEs) are one of the main classes of protein found in several different classes of plant-parasitic nematodes (29). Their diversity in the $\mathrm{CN}$ and RKN genomes are unique in the animal kingdom $(1,13,27,45$, 92). By contrast, other extended families, e.g. secreted SPRY domain-containing proteins (SPYSECs) (36), and hypervariable extracellular effectors (HYPs) (46), have only been characterized in CNs. Cis-regulatory elements were identified in the promoters of $\mathrm{CN}$ effector genes specifically expressed within the DG specific, called DOG ("DOrsal Gland") boxes (44, 92). The presence of these motifs identifies the effector-encoding genes they contain as being regulated by key transcription factors and opens up new possibilities for effector prediction. Indeed, effectors meeting the predefined criteria may be missed (97). For example, several candidate effectors with no detectable signal peptide have been reported to be secreted but are not picked up by current genome-mining strategies. Nevertheless, genes of these candidate effectors have been shown to be specifically expressed in secretory organs frequently validated by in situ hybridization (ISH) (33). Despite the hundred or so ISH-validated effectors $(48,129)$, only a few candidate effectors have been demonstrated to be secreted in planta by immunolocalization. Several effectors have been shown to be delivered to the host apoplast and few have been shown to be translocated into the feeding cells (94).

In the gall-inducing-insects, more than 1,600 genes encoding effectors were found in Hessian fly (147). As for RKN and CN, most of these putative effector genes were supported by the presence of transcripts in salivary glands $(24,25)$. They are located in clusters on Hessian fly chromosomes and can be grouped into families and superfamilies (24). One of the unique features of these putative effector genes is their unconventional conservation patterns, with strong conservation of the $5^{\prime}$ - and $3^{\prime}$-untranslated regions and the signal peptide-coding regions, 
but highly diversified protein-coding regions (24). This unconventional conservation pattern is also found in other related gall midges $(3,4)$. The functional significance of these unconventional conservation patterns in gall midge effector genes is unknown. High selection pressure from resistant host plants may have led to these unconventional conservation patterns through the selection of mutations in coding regions, increasing mismatching and unequal recombination during mitosis to generate high rates of mutation in effector genes. However, the presence of insect effectors in host plants remains largely unstudied and only a handful of effectors have been detected in plant tissues to date (137).

\section{Plant-Reprogramming Effector Functions in Interactions with Plants}

Most candidate nematode and insect-galling effectors have no clearly identified function. The functions of only a few have been deciphered. PCWDEs have been reported to facilitate nematode penetration and migration within the root and to play a role in the cell wall expansion and thickening associated with feeding cell formation (30). Galling insects also produce their own plant cell wall-degrading enzymes (64). The larvae of the oak gall cynipid Biorhyza palida and the gall-inducing moth Caloptilia cecidophora, strongly expressed chitinase genes during gall induction. These chitinases may modify arabinogalactan proteins in the matrix of plant tissues, thereby triggering an embryogenesis-like dedifferentiation and stimulating cell division in plant tissues. RKN and CN secrete chorismate mutases, which act on the plant shikimate pathway, that may prevent the triggering of host defenses by decreasing the synthesis of SA, and, subsequently, of phytoalexins, through competition with chorismate (131). A few proteins with known functions, such as proteases and protease inhibitors have been identified in gall midges. They may affect protease-related pathways if they are indeed injected into host plants. The Hessian fly NDK may probably regulate the abundance of nucleoside phosphates in host plants and affect a range of host metabolic pathways (137).

Several CN and RKN effectors have been shown to interfere with plant defense responses (55, 105), e.g., . MiCRT , MiTTL5 , Hs4E02 (87, 103) . In addition, the only identifiable motifs frequently observed are localization motifs, such as the nuclear localization signal (NLS). The presence of NLS motifs in several effectors suggests that these molecules may target the host cell nucleus $(39,65,105)$.

Nematodes are also able to produce peptide effectors mimicking plant hormone signaling peptides to modulate root cell hormonal balance and promote feeding-site formation (50). Given 
the importance of modulating phytohormone in plant manipulation, it would not be surprizing that insects may use similar strategies These peptides include CLE (CLAVATA3/EMBRYO SURROUNDING REGION) in CNs (98), and IDAs (INFLORESCENCE-DEFICIENT IN ABSCISSION) and CEPs (C-TERMINALLY ENCODED PEPTIDE) in RKNs (12, 79). In addition, CLE-like domains were identified in some RKN effectors, e.g. MAP protein family and 16D10 $(69,109)$. CN CLE peptides have been shown to act through the plant receptor kinases CORYNE and CLAVATA2, driving the presyncytial cells toward specific developmental programs required for feeding-cell initiation (106). CLE signaling and genes more generally involved in meristem initiation, maintenance or growth are also upregulated by Phylloxera during galling on wild grapevine (111).

Identification of the plant cell compartments to which plant-reprogrammer secreted proteins are targeted can provide evidence for potential molecular functions. Immunolocalization techniques have provided reliable data concerning the distribution of effectors within host cells. For nematode-secreted proteins, the apoplasm has been identified as an important destination compartment during migration and feeding-cell formation in the host plant (133). Interestingly, three RKN effectors have been shown to be targeted to the nucleus of feeding cells and a few, such as MiMIF2, have been shown to be targeted to the cytoplasm $(94,148)$. The targeting of the host nucleus by plant-reprogrammer effectors reflects a need for the manipulation of various nuclear processes to modify plant cell fate and immunity during the ontogeny of feeding cells.

\section{Plant Targets of Plant-Reprogramming Effectors}

Plant-reprogramming effectors must interact with host proteins or mimic plant proteins or other signaling molecules to manipulate plant physiology and defenses $(65,94)$. Recent functional analyses have focused on the identification of their direct targets in the plant. In fact, the identification of plant targets for insect effectors is still at an early stage. Only a few targets of insect effectors have been identified, and none from galling and leaf-mining insects. The few studies performed to date indicate that insect effectors target various plant pathways, suppressing plant defenses or increasing access to nutrients (41). On the contrary, the first targets of nematode effectors for the formation of the feeding site per se are beginning to emerge. Nematode effectors have been shown to subvert immunity by interacting with plant proteins to scavenge the ROS accumulating during the PTI oxidative burst. For example, $M$. javanica MjTTL5 interacts with an Arabidopsis thioredoxin reductase catalytic subunit (87). The $H$. 
schachtii Hs10A06 pioneer interacts with an Arabidopsis spermidine synthase (AtSPDS2) to enhance spermidine production and induce ROS scavenging(66). RKN (e.g., M. graminicola MgMO237) and CN (e.g., H. glycines $\mathrm{Hg} 30 \mathrm{CO} 2$ and G. rostochiensis GrVAP-1) effectors directly target several PR proteins to block the production of antimicrobial proteins by plants $(23,62,90)$ In contrast, few effectors have been shown to contribute to feeding-site formation. This is the case for the actin-binding protein MiPFN3 (85) and a G. pallida effector, GpSPRY414-2, that has been shown to bind to a potato microtubule-associated protein (93). Two other effectors, H. schachtii Hs19C07 and Hs10A07, have been shown to modulate auxin signaling by interacting with and increasing the activity of the Arabidopsis auxin transporter LAX3 (84) and by affecting the expression of auxin-responsive factors (ARFs) (67), respectively, thereby facilitating the formation of $\mathrm{CN}$ feeding sites. Finally, some RKN and $\mathrm{CN}$ effectors have been shown to target key processes regulating host gene expression. The H. schachtii Hs32E03 effector alters the acetylation of histones by interacting with the Arabidopsis histone deacetylase HDT1 and the FK506-binding protein FKBP53 in the nucleus (134). Several nuclear effectors have also been shown to target transcription factors. The $M$. incognita Mi16D10, containing a Cterminal CLE-like domain, interacts with tomato and Arabidopsis SCARECROW-like transcription factors to modulate root development (69). Another example is provided by $H$. schachtii Hs10A07, which is secreted into the cytoplasm, phosphorylated by an Arabidopsis kinase, and translocated to the nucleus, where it interacts with an Aux/IAA transcription factor, IAA16, to modulate ARF expression (67). Other effectors, such as H. glycines HgGLAND4 and M. incognita 7H08, bind DNA directly to modulate gene transcription (7, 94). Finally, $H$. schachtii Hs30D08 has been shown to interact with a component of the spliceosome machinery, the Arabidopsis auxiliary spliceosomal protein SMU2, and interfere with mRNA splicing, thereby altering gene expression at feeding sites (132).

Among all the targets identified to date, it is interesting to note that some of them constitute hub plant targets, such as subunit 5 of the COP9 signalosome (CSN5) which is a regulatory component of the ubiquitin/proteasome system, targeted by bacterial, fungal, viral, and nematode effectors (17). It will be interesting to determine whether effectors from galling and leaf-mining insects target such evolutionarily conserved pathogen host targets.

\section{IMPLICATIONS IN AGRICULTURE AND FORESTRY}


Outside of the small number of model systems, we are only just beginning to understand the manipulation of plants by these plant-reprogramming insects and nematodes, and this is hampering the development of novel, robust management strategies in agriculture and forestry.

\section{Targeting Susceptibility Genes in the Context of Community Ecology}

Dominant resistance genes are typically used to confer resistance against parasites. However, relatively few resistance genes against plant-manipulating nematodes and insects are used, and such resistance genes are usually rapidly overcome by these plant parasites. Improvements in our understanding of these interactions would make it possible to develop new strategies based on the loss of plant genes (susceptibility genes) essential for the development of the parasite (40, 130). Interfering with the establishment and functioning of the feeding/nutritive cells essential for these endoparasitic plant-reprogrammers appears to be a particularly suitable strategy to control them. Plant genes targeted by parasite effectors are good candidates for susceptibility genes. The mutation of some of these genes can decrease infection. The loss of these susceptibility genes could therefore be engineered into crop plants to provide more durable, broader-spectrum resistance. However, susceptibility genes have functions in plant development, and the possible adverse effects of their mutation should therefore be analyzed in terms of plant functional traits and cascading effects on beneficial organisms associated with the plant (130). Indeed, plants interact with many different biotic partners. Some of these relationships are very complex and involve both detrimental and beneficial organisms. Comparative genomics has made it possible to identify genes that are more broadly conserved across plant-parasitic species but nevertheless restricted to such species (28). These genes may be considered to play an important role in the plant-parasitic lifestyle while being relatively nontoxic to other beneficial organisms. They represent specific key targets essential for the life cycle of the infecting organism only. In this respect, genes specific to plant parasites are promising targets for the identification of new antiparasitic strategies.

Plants are associated with a large community of microorganisms, whose roles in parasitic interactions have been little investigated. Well-characterized molecular mechanisms used by plant-associated microorganisms, whether beneficial or detrimental to the host plant, can provide us with opportunities to improve our understanding of interactions between plant-manipulating insects/nematodes and their host plants(54). Indeed, some of the mechanisms used by parasitic nematodes and insects to manipulate the host plant have also been shown to be involved in 
establishing interactions between plants and their beneficial symbiotic microorganisms. For example, apyrases are essential for rhizobial and mycorrhizal symbioses, presumably because of their ability to modulate eATP levels (124). In legumes, bacterial symbionts may enhance plant colonization by modulating apyrase activity with lipochito-oligosaccharide Nod factors to control the infection and nodulation processes $(31,76,124)$. This knowledge may prove useful for the development of efficient and innovative antiparasitic strategies. Detailed functional metagenomics analyses will also facilitate characterization of the diversity, richness, and functions of genes involved in interactions between plants and their phytobiome, and connections between plant-associated and parasite-associated micro-organisms may emerge from these studies. This may pave the way for new areas of research and exciting perspectives for improving our understanding of plant-biotic interactions and developing innovative microbeinduced control strategies for agricultural pests.

\section{Targeting Symbionts as an Effective Resistance Strategy}

Promising developments can also be expected in relation to the intricate ecology of plantmanipulating organisms. The potential presence of a diverse assemblage of endosymbiotic bacteria in gall inducers may strongly influence their hosts biology and manipulation. Wolbachia is one of the most intensively studied symbionts since it is found in up to $70 \%$ of insect species and in many terrestrial arthropods, and can manipulate host reproductive biology. Cases of Wolbachia infection in plant-parasitic nematodes have only been reported in Radopholus and Pratylenchus $(19,61,138)$. In the leaf-miner caterpillar Phyllonorycter blancardella, the presence of Wolbachia alters the phytohormonal profiles of the leaf to create an enhanced nutritional microenvironment $(14,75)$. Wolbachia may manipulate reproduction in these species, but they are not obligate mutualists. While no microbial symbionts have been detected in RKN to date. Candidatus Cardinium hertigii infect the $\mathrm{CN}$ G. rostochiensis, $H$. glycines and $H$. goettingiana and was also found in four parasitic wasp species $(100,102,143)$. Nonetheless the role of this bacteria is still to be elucidated, this is to date the only endosymbiotic bacteria identified so far that is common to nematode and insect gall inducers.

Progresses have been made in recent years describing the microbial diversity associated with insects as symbionts seem to be instrumental in plant-insect interactions, with important implications for plant defenses and plant utilization by insects. Microbial symbionts of plantreprogramming insects can directly or indirectly interfere with a number of components of plant 
metabolism and defense $(14,51,59)$. For example, diverse microbes in the digestive systems and salivary glands of insects can modify oral secretions to enable the insect to evade plant defenses (26). Insects can also act as vectors, carrying bacteria capable of suppressing ROS-mediated plant defenses to and from feeding sites (56). Insect microbial symbionts can also affect plant nutritional quality and morphology by modifying the phytohormonal profile of attacked plant tissues $(75,144,146)$. Some gall midges also have symbiotic associations with biotrophic fungi that are essential for plant invasion and gall development (108). Various control options could be pursued, including disrupting the vertical transmission (mother to offspring) of obligate endosymbionts required for insect growth, nutrition, reproduction, and survival (6). However, common antibiotics cannot be used for field applications because of both environmental and public health concerns, even though they have been shown to be effective for this purpose . A new alternative for pest control known as symbiotic control is based on the disruption of symbiosis between the pest and its associated microorganisms $(6,51,52)$.

Microbial effectors affecting plant-parasite interactions can be encoded by genes incorporated into insect and nematode gall inducer genomes following horizontal gene transfer (HGT) from bacteria $(16,29)$. HGT is particularly widespread in arthropods, probably because of the close association of many insects with endosymbionts, although the adaptive significance of the transferred genes is not always clear (140). The HGT of genes encoding PCWDEs or genes encoding enzymes involved in plant carbohydrate metabolism, has been detected in cynipid gall wasps (21) Hessian fly (147), CN and RKNs $(29,116)$. This suggests that the acquisition of genes by HGT may play an important role in transitions to plant-parasitic lifestyles and in feeding on specific host plants or tissues.

\section{CONCLUSIONS}

This review advocates for closer collaboration between plant pathologists, entomologists, and microbiologists to determine the extent to which similarities between plant parasites reflect shared ancestral traits or convergent evolution in the face of similar constraints imposed by the endophytic lifestyle of sedentary endoparasitic nematodes and gall-inducing and leaf-mining insects. The development of new sequencing techniques applicable to non-model species and the search for ecological models with multiple parasite species from distinct feeding guilds on a single host-plant will accelerate the identification of effectors and facilitate comparative studies 
between insects and plant-reprogramming nematodes. Similarly, an integrated approach to the expression models for plant genes and the salivary effectors produced by these plant reprogrammers will undoubtedly help to identify the plant functions targeted. This should make it easier to decipher the strategies used by these parasites to manipulate their host plants, paving the way for the discovery of the mechanisms underlying the induction and growth of these de novo structures. Finally, in the most advanced study models, RNA interference or genomeediting approaches may improve our understanding of the proximal mechanisms underlying host manipulation.

Future studies will also provide valuable insight into the mechanisms of plant manipulation by insects and nematodes and the roles played by the symbionts or microorganisms with which they are associated. Insect and nematode lifestyles and their evolution are probably strongly influenced by the microorganisms that establish symbiotic associations with them, ranging from obligate symbiosis to looser forms, characterized by more flexible assemblages of open microbial communities. However, field applications for managing or controlling these agricultural or forest pests through the direct targeting of its associated microbes will need to take into account environmental and public health concerns about their implementation.

\section{DISCLOSURE STATEMENT}

The authors are not aware of any affiliations, memberships, funding, or financial holdings that might be perceived as affecting the objectivity of the review.

\section{ACKNOWLEDGMENTS}

We thank Dr. Marion Harris (Department of Entomology, North Dakota State University, USA) and Dr. Michaël Quentin (INRAE, Université Côte d'Azur, CNRS, ISA, France) for critical reading of the manuscript and suggestions, and Antoine Guiguet (IRBI - CNRS, Université de Tours) for providing pictures. B.F. and P.A. were supported by the Institut National de la Recherche Agronomique (INRA) and by the French National Research Agency (ANR) through the "Investments for the Future" LABEX SIGNALIFE: program reference \# ANR-11-LABX0028-01. D.G. and G.D. were supported by the Centre National de la Recherche Scientifique 
(CNRS), the University of Tours and the Région Centre-Val de Loire project INSECTEFFECT (\#2014-00094521). We apologize to researchers whose work was not mentioned or cited in this review owing to space and cited literature limitations.

\section{LITERATURE CITED}

1. Abad P, Rosso MN, Castagnone-Sereno P, de Almeida-Engler J, Favery B. 2009. Invasion, feeding and development. In Root-knot nematodes, ed RN Perry, M Moens, JL Starr, pp. 163-81. King's Lynn, UK: CABI

2. Aditya J, Lewis J, Shirley NJ, Tan HT, Henderson M, et al. 2015. The dynamics of cereal cyst nematode infection differ between susceptible and resistant barley cultivars and lead to changes in $(1,3 ; 1,4)-\beta$-glucan levels and HvCslF gene transcript abundance. New Phytologist. 207:135-47

3. Al-Jbory Z, Anderson KM, Harris MO, Mittapalli O, Whitworth RJ, Chen M-S. 2018. Transcriptomic analyses of secreted proteins from the salivary glands of wheat midge larvae. Journal of Insect Science. 18:17

4. Al-Jbory Z, El-Bouhssini M, Chen MS. 2018. Conserved and unique putative effectors expressed in the salivary glands of three related gall midge species. Journal of Insect Science. 18:15

5. Amjad Ali M, Wieczorek K, Kreil DP, Bohlmann H. 2014. The beet cyst nematode Heterodera schachtii modulates the expression of WRKY transcription factors in syncytia to favour its development in Arabidopsis roots. PLoS ONE. 9:e102360

6. Arora AK, Douglas AE. 2017. Hype or opportunity? Using microbial symbionts in novel strategies for insect pest control. Journal of Insect Physiology. 103:10-17

7. Barnes SN, Wram CL, Mitchum MG, Baum TJ. 2018. The plant-parasitic cyst nematode effector GLAND4 is a DNA-binding protein. Molecular Plant Pathology. 19:2263-76

8. Bartlem DG, Jones MGKK, Hammes UZ. 2014. Vascularization and nutrient delivery at root-knot nematode feeding sites in host roots. Journal of Experimental Botany. 65:178998

9. Bartlett L, Connor EF. 2014. Exogenous phytohormones and the induction of plant galls by insects. Arthropod-Plant Interactions. 8:339-48

10. Bellafiore S, Shen Z, Rosso M-NN, Abad P, Shih P, Briggs SP. 2008. Direct identification 
of the Meloidogyne incognita secretome reveals proteins with host cell reprogramming potential. PLoS pathogens. 4:e1000192

11. Bert W, Karssen G, Helder J. 2011. Phylogeny and evolution of nematodes. In Genomics and Molecular Genetics of Plant-Nematode Interactions, ed J Jones, G Gheysen, C Fenoll, pp. 45-59. Springer Netherlands

12. Bird DMK, Jones JT, Opperman CH, Kikuchi T, Danchin TGJ, Danchin EGJJ. 2014. Signatures of adaptation to plant parasitism in nematode genomes. Parasitology. 142:1-14

13. Blanc-Mathieu R, Perfus-Barbeoch L, Aury JM, Da Rocha M, Gouzy J, et al. 2017. Hybridization and polyploidy enable genomic plasticity without sex in the most devastating plant-parasitic nematodes. PLoS Genetics. 13:e1006777

14. Body M, Kaiser W, Dubreuil G, Casas J, Giron D. 2013. Leaf-Miners Co-opt Microorganisms to Enhance their Nutritional Environment. Journal of Chemical Ecology. 39:969-77

15. Bohlmann H, Sobczak M. 2014. The plant cell wall in the feeding sites of cyst nematodes. Frontiers in Plant Science. 5:89

16. Boto L. 2014. Horizontal gene transfer in the acquisition of novel traits by metazoans. Proceedings of the Royal Society B: Biological Sciences. 281:20132450

17. Bournaud C, Gillet F-X, Murad AM, Bresso E, Albuquerque EVS, Grossi-de-Sá MF. 2018. Meloidogyne incognita PASSE-MURAILLE (MiPM) gene encodes a cellpenetrating protein that interacts with the CSN5 subunit of the COP9 signalosome. Frontiers in Plant Science. 9:904

18. Bozbuga R, Lilley CJ, Knox JP, Urwin PE. 2018. Host-specific signatures of the cell wall changes induced by the plant parasitic nematode, Meloidogyne incognita. Scientific Reports. 8:17302

19. Brown AMV, Wasala SK, Howe DK, Peetz AB, Zasada IA, Denver DR. 2018. Comparative genomics of wolbachia-cardinium dual endosymbiosis in a plant-parasitic nematode. Frontiers in Microbiology

20. Cabrera J, Bustos R, Favery B, Fenoll C, Escobar C. 2014. NEMATIC: a simple and versatile tool for the in silico analysis of plant-nematode interactions. Molecular Plant Pathology. 15:627-36

21. Cambier S, Ginis O, Moreau SJM, Gayral P, Hearn J, et al. 2019. Gall wasp 
transcriptomes unravel potential effectors involved in molecular dialogues with oak and rose. Frontiers in Physiology. 10:926

22. Čepulyte R, Danquah WB, Bruening G, Williamson VM. 2018. Potent attractant for rootknot nematodes in exudates from seedling root tips of two host species. Scientific Reports. $8: 10847$

23. Chen J, Hu L, Sun L, Lin B, Huang K, et al. 2018. A novel Meloidogyne graminicola effector, MgMO237, interacts with multiple host defence-related proteins to manipulate plant basal immunity and promote parasitism. Molecular Plant Pathology. 19:1942-55

24. Chen MS, Liu X, Yang Z, Zhao H, Shukle RH, et al. 2010. Unusual conservation among genes encoding small secreted salivary gland proteins from a gall midge. $B M C$ Evolutionary Biology. 10:296

25. Chen MS, Zhao HX, Zhu YC, Scheffler B, Liu X, et al. 2008. Analysis of transcripts and proteins expressed in the salivary glands of Hessian fly (Mayetiola destructor) larvae. Journal of Insect Physiology. 54:1-16

26. Chung SH, Rosa C, Scully ED, Peiffer M, Tooker JF, et al. 2013. Herbivore exploits orally secreted bacteria to suppress plant defenses. Proceedings of the National Academy of Sciences of the United States of America. 110:15728-33

27. Cotton J a, Lilley CJ, Jones LM, Kikuchi T, Reid AJ, et al. 2014. The genome and lifestage specific transcriptomes of Globodera pallida elucidate key aspects of plant parasitism by a cyst nematode. Genome biology. 15:R43

28. Danchin EGJ, Arguel M-J, Campan-Fournier A, Perfus-Barbeoch L, Magliano M, et al. 2013. Identification of novel target genes for safer and more specific control of root-knot nematodes from a pan-genome mining. PLoS pathogens. 9:e1003745

29. Danchin EGJ, Rosso M-NN, Vieira P, de Almeida-Engler J, Coutinho PM, et al. 2010. Multiple lateral gene transfers and duplications have promoted plant parasitism ability in nematodes. Proc Natl Acad Sci U S A. 107:17651-56

30. Davis EL, Haegeman A, Kikuchi T, Davies EL, Haegeman A, Kikuchi T. 2011. Degradation of the plant cell wall by nematodes. In Genomics and molecular genetics of plant-nematode interactions, ed J Jones, G Gheysen, C Fenoll, pp. 255-72. Dordrecht: Springer

31. Day RB, McAlvin CB, Loh JT, Denny RL, Wood TC, et al. 2000. Differential expression 
of two soybean apyrases, one of which is an early nodulin. Molecular Plant-Microbe Interactions. 13:1053-70

32. de Almeida Engler J, Gheysen G. 2013. Nematode-induced endoreduplication in plant host cells: why and how? Molecular Plant-Microbe Interactions. 26:17-24

33. De Boer JM, Yan Y, Smant G, Davis EL, Baum TJ. 1998. in-situ hybridization to messenger RNA in Heterodera glycines. Journal of nematology. 30:309-12

34. De Meutter J, Tytgat T, Prinsen E, Gheysen G, Van Onckelen H. 2005. Production of auxin and related compounds by the plant parasitic nematodes Heterodera schachtii and Meloidogyne incognita. Commun Agric Appl Biol Sci. 70:51-60

35. Detoni M de L, Faria-Pinto P, Quellis LR, Rust NM, Tavares LS, et al. 2012. Galls from Calliandra brevipes BENTH (Fabaceae : Mimosoidae): evidence of apyrase activity contribution in a plant-insect interaction. Australian Journal of Botany. 60:559-67

36. Diaz-Granados A, Petrescu AJ, Goverse A, Smant G. 2016. SPRYSEC effectors: A versatile protein-binding platform to disrupt plant innate immunity. Frontiers in Plant Science. $7: 1575$

37. Dowd CD, Chronis D, Radakovic ZS, Siddique S, Schmülling T, et al. 2017. Divergent expression of cytokinin biosynthesis, signaling and catabolism genes underlying differences in feeding sites induced by cyst and root-knot nematodes. The Plant Journal. 92:211-28

38. Dubreuil G, Deleury E, Magliano M, Jaouannet M, Abad P, Rosso M-NN. 2011. Peroxiredoxins from the plant parasitic root-knot nematode, Meloidogyne incognita, are required for successful development within the host. International Journal for Parasitology. 41:385-96

39. Elling AA, Davis EL, Hussey RS, Baum TJ. 2007. Active uptake of cyst nematode parasitism proteins into the plant cell nucleus. International Journal for Parasitology. 37:1269-79

40. Engler J de A, Favery B, Engler G, Abad P. 2005. Loss of susceptibility as an alternative for nematode resistance. Current Opinion in Biotechnology. 16:112-17

41. Erb M, Reymond P. 2019. Molecular interactions between plants and insect herbivores. Annual Review of Plant Biology. 70:527-57

42. Escobar C, Brown S, Mitchum M. 2011. Transcriptomic and proteomic analysis of the 
plant response to nematode infection. In Genomics and Molecular Genetics of PlantNematode Interactions, ed J Jones, G Gheysen, C Fenoll, pp. 157-73. Dordrecht, Heidelberg, London \& New York: Springer

43. Escudero Martinez CM, Guarneri N, Overmars H, van Schaik C, Bouwmeester H, et al. 2019. Distinct roles for strigolactones in cyst nematode parasitism of Arabidopsis roots. European Journal of Plant Pathology. 154:129-40

44. Eves-van den Akker S, Birch PRJ. 2016. Opening the effector protein toolbox for plantparasitic cyst nematode interactions. Molecular Plant. 9:1451-53

45. Eves-van den Akker S, Laetsch DR, Thorpe P, Lilley CJ, Danchin EGJ, et al. 2016. The genome of the yellow potato cyst nematode, Globodera rostochiensis, reveals insights into the basis of parasitism and virulence. Genome Biology. 17:124

46. Eves-van den Akker S, Lilley CJ, Jones JT, Urwin PE. 2014. Identification and characterisation of a hyper-variable apoplastic effector gene family of the potato cyst nematodes. PLoS Pathogens. 10:e1004391

47. Favery B, Quentin M, Jaubert-Possamai S, Abad P. 2016. Gall-forming root-knot nematodes hijack key plant cellular functions to induce multinucleate and hypertrophied feeding cells. Journal of Insect Physiology. 84:60-69

48. Gardner M, Verma A, Mitchum MG. 2015. Emerging roles of cyst nematode effectors in exploiting plant cellular processes. In Advances in Botanical Research, ed C Escobar, C Fenoll, pp. 259-91. Elsevier

49. Gheysen G, Mitchum MG. 2011. How nematodes manipulate plant development pathways for infection. Current Opinion in Plant Biology. 14:415-21

50. Gheysen G, Mitchum MG. 2019. Phytoparasitic nematode control of plant hormone pathways. Plant Physiology. 179:1212-26

51. Giron D, Dedeine F, Dubreuil G, Huguet E, Mouton L, et al. 2017. Influence of microbial symbionts on plant-insect interactions. In Advances in botanical research, ed S Nicolas, D Thiéry, P-A Calatayud. 81:225-57. Elsevier

52. Giron D, Dubreuil G, Bennett A, Dedeine F, Dicke M, et al. 2018. Promises and challenges in insect-plant interactions. Entomologia Experimentalis et Applicata. 166:319-43

53. Giron D, Frago E, Glevarec G, Pieterse CMJ, Dicke M. 2013. Cytokinins as key 
regulators in plant-microbe-insect interactions: connecting plant growth and defence. Functional Ecology. 27:599-609

54. Giron D, Huguet E, Stone GN, Body M. 2016. Insect-induced effects on plants and possible effectors used by galling and leaf-mining insects to manipulate their host-plant. Journal of Insect Physiology. 84:70-89

55. Goverse A, Smant G. 2014. The activation and suppression of plant innate immunity by parasitic nematodes. Annual review of phytopathology. 52:1-23

56. Groen SC, Humphrey PT, Chevasco D, Ausubel FM, Pierce NE, Whiteman NK. 2016. Pseudomonas syringae enhances herbivory by suppressing the reactive oxygen burst in Arabidopsis. Journal of Insect Physiology. 84:90-102

57. Grundler FMW, Hofmann J. 2011. Water and nutrient transport in nematode feeding sites. In Genomics and Molecular Genetics of Plant-Nematode Interactions, pp. 423-39.

Dordrecht: Springer Netherlands

58. Guiguet A, Dubreuil G, Harris MO, Appel HM, Schultz JC, et al. 2016. Shared weapons of blood- and plant-feeding insects: Surprising commonalities for manipulating hosts. Journal of Insect Physiology. 84:4-21

59. Guiguet A, Hamatani A, Amano T, Takeda S, Lopez-Vaamonde C, et al. 2018. Inside the horn of plenty: Leaf-mining micromoth manipulates its host plant to obtain unending food provisioning. PLOS ONE. 13:e0209485

60. Guiguet A, Ohshima I, Takeda S, Laurans F, Lopez-Vaamonde C, Giron D. 2019. Origin of gall-inducing from leaf-mining in Caloptilia micromoths (Lepidoptera, Gracillariidae). Scientific Reports. 9:6794

61. Haegeman A, Vanholme B, Jacob J, Vandekerckhove TTM, Claeys M, et al. 2009. An endosymbiotic bacterium in a plant-parasitic nematode: Member of a new Wolbachia supergroup. International Journal for Parasitology. 39:1045-54

62. Hamamouch N, Li C, Hewezi T, Baum TJ, Mitchum MG, et al. 2012. The interaction of the novel $30 \mathrm{C} 02$ cyst nematode effector protein with a plant $\beta-1,3$-endoglucanase may suppress host defence to promote parasitism. Journal of Experimental Botany. 63:3683-95

63. Harris MO, Freeman TP, Rohfritsch O, Anderson KG, Payne SA, Moore JA. 2006. Virulent Hessian fly (Diptera: Cecidomyiidae) larvae induce a nutritive tissue during compatible interactions with wheat. Annals of the Entomological Society of America. 
99:305-16

64. Hearn J, Blaxter M, Schönrogge K, Nieves-Aldrey J-L, Pujade-Villar J, et al. 2019. Genomic dissection of an extended phenotype: Oak galling by a cynipid gall wasp. PLOS Genetics. 15:e1008398

65. Hewezi T, Baum TJ. 2013. Manipulation of plant cells by cyst and root-knot nematode effectors. Molecular Plant-Microbe Interactions. 26:9-16

66. Hewezi T, Howe PJ, Maier TR, Hussey RS, Mitchum MG, et al. 2010. Arabidopsis spermidine synthase is targeted by an effector protein of the cyst nematode Heterodera schachtii. Plant Physiology. 152:968-84

67. Hewezi T, Juvale PS, Piya S, Maier TR, Rambani A, et al. 2015. The Cyst Nematode Effector Protein 10A07 Targets and recruits host posttranslational machinery to mediate its nuclear trafficking and to promote parasitism in arabidopsis. The Plant Cell. 27:891907

68. Holbein J, Grundler FMW, Siddique S. 2016. Plant basal resistance to nematodes: an update. Journal of Experimental Botany. 67:2049-61

69. Huang G, Dong R, Allen R, Davis EL, Baum TJ, Hussey RS. 2006. A root-knot nematode secretory peptide functions as a ligand for a plant transcription factor. Mol Plant Microbe Interact. 19:463-70

70. Jaubert-Possamai S, Noureddine Y, Favery B. 2019. MicroRNAs, New players in the plant-nematode interaction. Frontiers in Plant Science. 10:1180

71. Ji H, Gheysen G, Denil S, Lindsey K, Topping JF, et al. 2013. Transcriptional analysis through RNA sequencing of giant cells induced by Meloidogyne graminicola in rice roots. Journal of Experimental Botany. 64:3885-98

72. Ji R, Ye W, Chen H, Zeng J, Li H, et al. 2017. A salivary endo- $\beta$-1,4-glucanase acts as an effector that enables the brown planthopper to feed on rice. Plant Physiology

73. Jones JT, Haegeman A, Danchin EGJJ, Gaur HS, Helder J, et al. 2013. Top 10 plantparasitic nematodes in molecular plant pathology. Molecular Plant Pathology. 14:946-61

74. Jones MGK, Goto DB. 2011. Root-knot nematodes and giant cells. In Genomics and Molecular Genetics of Plant-Nematode Interactions, ed J Jones, G Gheysen, C Fenoll, pp. 83-100. Springer Netherlands

75. Kaiser W, Huguet E, Casas J, Commin C, Giron D. 2010. Plant green-island phenotype 
induced by leaf-miners is mediated by bacterial symbionts. Proceedings of the Royal Society B: Biological Sciences. 277:2311-19

76. Kalsi G, Etzler ME. 2000. Localization of a nod factor-binding protein in legume roots and factors influencing its distribution and expression. Plant Physiology. 124:1039-48

77. Kawazu K, Mochizuki A, Sato Y, Sugeno W, Murata M, et al. 2012. Different expression profiles of jasmonic acid and salicylic acid inducible genes in the tomato plant against herbivores with various feeding modes. Arthropod-plant interactions. 6:221-30

78. Khajuria C, Wang H, Liu X, Wheeler S, Reese JC, et al. 2013. Mobilization of lipids and fortification of cell wall and cuticle are important in host defense against Hessian fly. BMC Genomics. 14:423

79. Kim J, Yang R, Chang C, Park Y, Tucker ML. 2018. The root-knot nematode Meloidogyne incognita produces a functional mimic of the Arabidopsis inflorescence deficient in abscission signaling peptide. Journal of Experimental Botany. 69:3009-21

80. Kutsukake M, Uematsu K, Fukatsu T. 2019. Plant manipulation by gall-forming social aphids for waste management. Frontiers in Plant Science. 10:933

81. Kyndt T, Denil S, Haegeman A, Trooskens G, Bauters L, et al. 2012. Transcriptional reprogramming by root knot and migratory nematode infection in rice. New Phytologist. 196:887-900

82. Kyndt T, Goverse A, Haegeman A, Warmerdam S, Wanjau C, et al. 2016. Redirection of auxin flow in Arabidopsis thaliana roots after infection by root-knot nematodes. Journal of Experimental Botany. 67:4559-70

83. Lahari Z, Ullah C, Kyndt T, Gershenzon J, Gheysen G. 2019. Strigolactones enhance root- knot nematode ( Meloidogyne graminicola ) infection in rice by antagonizing the jasmonate pathway. New Phytologist. 224:454-65

84. Lee C, Chronis D, Kenning C, Peret B, Hewezi T, et al. 2011. The novel cyst nematode effector protein $19 \mathrm{c} 07$ interacts with the arabidopsis auxin influx transporter lax 3 to control feeding site development. Plant Physiology. 155:866-80

85. Leelarasamee N, Zhang L, Gleason C. 2018. The root-knot nematode effector MiPFN3 disrupts plant actin filaments and promotes parasitism. PLOS Pathogens. 14:e1006947

86. Lim PO, Kim HJ, Gil Nam H. 2007. Leaf senescence. Annual Review of Plant Biology. $58: 115-36$ 
87. Lin B, Zhuo K, Chen S, Hu L, Sun L, et al. 2016. A novel nematode effector suppresses plant immunity by activating host reactive oxygen species-scavenging system. $\mathrm{New}$ Phytologist. 209:1159-73

88. Liu X, Bai J, Huang L, Zhu L, Liu X, et al. 2007. Gene expression of different wheat genotypes during attack by virulent and avirulent Hessian fly (mayetiola destructor) larvae. Journal of Chemical Ecology. 33:2171-94

89. Liu X, Williams CE, Nemacheck JA, Wang H, Subramanyam S, et al. 2010. Reactive oxygen species are involved in plant defense against a gall midge. Plant Physiology. 152:985-99

90. Lozano-Torres JL, Wilbers RHP, Gawronski P, Boshoven JC, Finkers-Tomczak A, et al. 2012. Dual disease resistance mediated by the immune receptor $\mathrm{Cf}-2$ in tomato requires a common virulence target of a fungus and a nematode. Proceedings of the National Academy of Sciences of the United States of America. 109:10119-24

91. Manosalva P, Manohar M, von Reuss SH, Chen S, Koch A, et al. 2015. Conserved nematode signalling molecules elicit plant defenses and pathogen resistance. Nature Communications. 6:7795

92. Masonbrink R, Maier TR, Muppirala U, Seetharam AS, Lord E, et al. 2019. The genome of the soybean cyst nematode (Heterodera glycines) reveals complex patterns of duplications involved in the evolution of parasitism genes. BMC Genomics. 20:119

93. Mei Y, Wright KM, Haegeman A, Bauters L, Diaz-Granados A, et al. 2018. The Globodera pallida SPRYSEC effector GpSPRY-414-2 that suppresses plant defenses targets a regulatory component of the dynamic microtubule network. Frontiers in Plant Science. 9:1019

94. Mejias J, Truong NM, Abad P, Favery B, Quentin M. 2019. Plant proteins and processes targeted by parasitic nematode effectors. Frontiers in Plant Science. 10:970

95. Mendy B, Wang'ombe MW, Radakovic ZS, Holbein J, Ilyas M, et al. 2017. Arabidopsis leucine-rich repeat receptor-like kinase NILR1 is required for induction of innate immunity to parasitic nematodes. PLOS Pathogens. 13:e1006284

96. Meutter J De, Tytgat T, De Meutter J, Tytgat T, Witters E, et al. 2003. Identification of cytokinins produced by the plant parasitic nematodes Heterodera schachtii and Meloidogyne incognita. Molecular Plant Pathology. 4:271-77 
97. Mitchum MG, Hussey RS, Baum TJ, Wang X, Elling AA, et al. 2013. Nematode effector proteins: an emerging paradigm of parasitism. New Phytologist. 199:879-94

98. Mitchum MG, Wang X, Wang J, Davis EL. 2012. Role of nematode peptides and other small molecules in plant parasitism. Annual Review of Phytopathology. 50:175-95

99. Nahar K, Kyndt T, De Vleesschauwer D, Höfte M, Gheysen G. 2011. The jasmonate pathway is a key player in systemically induced defense against root knot nematodes in rice. Plant physiology. 157:305-16

100. Nakamura Y, Kawai S, Yukuhiro F, Ito S, Gotoh T, et al. 2009. Prevalence of cardinium bacteria in planthoppers and spider mites and taxonomic revision of "Candidatus cardinium hertigii" based on detection of a new cardinium group from biting midges. Applied and Environmental Microbiology. 75:6757-63

101. Nguyen C-N, Perfus-Barbeoch L, Quentin M, Zhao J, Magliano M, et al. 2018. A rootknot nematode small glycine and cysteine-rich secreted effector, MiSGCR1, is involved in plant parasitism. New Phytologist. 217:687-99

102. Noel GR. 2006. "Candidatus Paenicardinium endonii”, an endosymbiont of the plantparasitic nematode Heterodera glycines (Nemata: Tylenchida), affiliated to the phylum Bacteroidetes. International Journal of Systematic and Evolutionary Microbiology. 56:1697-1702

103. Pogorelko G V., Juvale PS, Rutter WB, Hütten M, Maier TR, et al. 2019. Retargeting of a plant defense protease by a cyst nematode effector. Plant Journal. 98: 1000-1014.

104. Poulin R, Randhawa HS. 2015. Evolution of parasitism along convergent lines: from ecology to genomics. Parasitology. 142:S6-15

105. Quentin M, Abad P, Favery B. 2013. Plant parasitic nematode effectors target host defense and nuclear functions to establish feeding cells. Frontiers in Plant Science. 4:53

106. Replogle A, Wang J, Bleckmann A, Hussey RS, Baum TJ, et al. 2011. Nematode CLE signaling in Arabidopsis requires CLAVATA2 and CORYNE. The Plant Journal. 65:430-40

107. Rodiuc N, Barlet X, Hok S, Perfus-Barbeoch L, Allasia V, et al. 2016. Evolutionarily distant pathogens require the Arabidopsis phytosulfokine signalling pathway to establish disease. Plant, Cell \& Environment. 39:1396-1407

108. Rohfritsch O. 2008. Plants, gall midges, and fungi: a three-component system. 
Entomologia Experimentalis et Applicata. 128:208-16

109. Rutter WB, Hewezi T, Maier TR, Mitchum MG, Davis EL, et al. 2014. Members of the meloidogyne avirulence protein family contain multiple plant ligand-like motifs. Phytopathology. 104:879-85

110. Sato K, Kadota Y, Shirasu K. 2019. Plant immune responses to parasitic nematodes. Frontiers in Plant Science. 10:1165

111. Schultz JC, Edger PP, Body MJA, Appel HM. 2019. A galling insect activates plant reproductive programs during gall development. Scientific Reports. 9:1833

112. Shah SJ, Anjam MS, Mendy B, Anwer MA, Habash SS, et al. 2017. Damage-associated responses of the host contribute to defence against cyst nematodes but not root-knot nematodes. Journal of Experimental Botany. 68:5949-60

113. Shih T-H, Lin S-H, Huang M-Y, Sun C-W, Yang C-M. 2018. Transcriptome profile of cup-shaped galls in Litsea acuminata leaves. PLOS ONE. 13:e0205265

114. Siddique S, Radakovic ZS, De La Torre CM, Chronis D, Novák O, et al. 2015. A parasitic nematode releases cytokinin that controls cell division and orchestrates feeding site formation in host plants. Proceedings of the National Academy of Sciences. 112:12669-74

115. Simonetti E, Veronico P, Melillo MT, Delibes A, Andrés MF, López-Braña I. 2009. Analysis of class III peroxidase genes expressed in roots of resistant and susceptible wheat lines infected by Heterodera avenae. Molecular plant-microbe interactions. 22:1081-92

116. Smant G, Stokkermans JP, Yan Y, de Boer JM, Baum TJ, et al. 1998. Endogenous cellulases in animals: isolation of beta-1, 4-endoglucanase genes from two species of plant-parasitic cyst nematodes. Proceedings of the National Academy of Sciences of the United States of America. 95:4906-11

117. Sobczak M, Golinowski W. 2009. Structure of cyst nematode feeding sites. In: Cell biology of plant nematode parasitism. Plant cell monographs, Berg R.H., Taylor C.G. (eds) vol 15. Springer, Berlin, Heidelberg

118. Stahl E, Hilfiker O, Reymond P. 2018. Plant-arthropod interactions: who is the winner? The Plant Journal. 93:703-28

119. Stone GN, Schönrogge K. 2003. The adaptive significance of insect gall morphology. Trends in Ecology and Evolution. 18:512-22

120. Stone GN, Schönrogge K, Atkinson RJ, Bellido D, Pujade-Villar J. 2002. The population 
biology of oak gall wasps (Hymenoptera: Cynipidae). Annual Review of Entomology. 47:633-68

121. Stuart JJ, Chen M-S, Shukle R, Harris MO. 2012. Gall midges (Hessian flies) as plant pathogens. Annual Review of Phytopathology. 50:339-57

122. Takeda S, Yoza M, Amano T, Ohshima I, Hirano T, et al. 2019. Comparative transcriptome analysis of galls from four different host plants suggests the molecular mechanism of gall development. PLOS ONE. 14:e0223686

123. Takei M, Yoshida S, Kawai T, Hasegawa M, Suzuki Y. 2015. Adaptive significance of gall formation for a gall-inducing aphids on Japanese elm trees. Journal of Insect Physiology. 72:43-51

124. Tanaka K, Choi J, Cao Y, Stacey G. 2014. Extracellular ATP acts as a damage-associated molecular pattern (DAMP) signal in plants. Frontiers in Plant Science. 5:446

125. Teixeira MA, Wei L, Kaloshian I. 2016. Root-knot nematodes induce pattern-triggered immunity in Arabidopsis thaliana roots. New Phytologist. 211:276-87

126. Tokuda M, Jikumaru Y, Matsukura K, Takebayashi Y, Kumashiro S, et al. 2013. Phytohormones related to host plant manipulation by a gall-inducing leafhopper. PLOS ONE. 8:e62350

127. Tooker JF, De Moraes CM. 2011. Feeding by a gall-inducing caterpillar species alters levels of indole-3-acetic and abscisic acid in Solidagoaltissima (Asteraceae) stems. Arthropod-Plant Interactions. 5:115-24

128. Tooker JF, Helms AM. 2014. Phytohormone dynamics associated with gall insects, and their potential role in the evolution of the gall-inducing habit. Journal of Chemical Ecology. 40:742-53

129. Truong NM, Nguyen C-N, Abad P, Quentin M, Favery B. 2015. Function of root-knot nematode effectors and their targets in plant parasitism. In Advance in Botanical Research: Plant Nematode Interactions A View on Compatible Interrelationships, ed C Escobar, C Fenoll. 73:293-324. Academic Press

130. van Schie CCN, Takken FLW. 2014. Susceptibility genes 101: how to be a good host. Annual Review of Phytopathology. 52:551-81

131. Vanholme B, Kast P, Haegeman A, Jacob J, Grunewald W, Gheysen G. 2009. Structural and functional investigation of a secreted chorismate mutase from the plant-parasitic 
nematode Heterodera schachtii in the context of related enzymes from diverse origins. Molecular Plant Pathology

132. Verma A, Lee C, Morriss S, Odu F, Kenning C, et al. 2018. The novel cyst nematode effector protein 30D08 targets host nuclear functions to alter gene expression in feeding sites. New Phytologist. 219:697-713

133. Vieira P, Danchin EGJ, Neveu C, Crozat C, Jaubert S, et al. 2011. The plant apoplasm is an important recipient compartment for nematode secreted proteins. Journal of experimental botany. 62:1241-53

134. Vijayapalani P, Hewezi T, Pontvianne F, Baum TJ. 2018. An effector from the cyst nematode Heterodera schachtii derepresses host rrna genes by altering histone acetylation. The Plant Cell. 30:2795-2812

135. Viney M. 2017. How can we understand the genomic basis of nematode parasitism? Trends in Parasitology. 33:444-52

136. Wang X-R, Moreno YA, Wu H-R, Ma C, Li Y, et al. 2012. Proteomic profiles of soluble proteins from the esophageal gland in female Meloidogyne incognita. International Journal for Parasitology. 42:1177-83

137. Wang Z, Ge JQ, Chen H, Cheng X, Yang Y, et al. 2018. An insect nucleoside diphosphate kinase (NDK) functions as an effector protein in wheat - Hessian fly interactions. Insect Biochemistry and Molecular Biology

138. Wasala SK, Brown AM V., Kang J, Howe DK, Peetz AB, et al. 2019. Variable abundance and distribution of Wolbachia and Cardinium endosymbionts in plant-parasitic nematode field populations. Frontiers in Microbiology. 10:964

139. Weinstein SB, Kuris AM. 2016. Independent origins of parasitism in Animalia. Biology Letters. 12:20160324

140. Werren JH, Richards S, Desjardins CA, Niehuis O, Gadau J, et al. 2010. Functional and evolutionary insights from the genomes of three parasitoid Nasonia species. Science. $327: 343-48$

141. Wool D. 2005. Gall-inducing aphids: biology, ecology, and evolution. Biology, ecology and evolution of gall-inducing arthropods, pp. 73-132

142. Yamaguchi H, Tanaka H, Hasegawa M, Tokuda M, Asami T, Suzuki Y. 2012. Phytohormones and willow gall induction by a gall-inducing sawfly. New Phytologist. 
196:586-95

143. Zchori-fein E, Perlman SJ. 2004. Distribution of the bacterial symbiont Cardinium in arthropods. Molecular Ecology. 13:2009-16

144. Zhang H, Dubreuil G, Faivre N, Dobrev P, Kaiser W, et al. 2018. Modulation of plant cytokinin levels in the $\mathrm{W}$ olbachia-free leaf-mining species $\mathrm{P}$ hyllonorycter mespilella. Entomologia Experimentalis et Applicata. 166:428-38

145. Zhang H, Dugé de Bernonville T, Body M, Glevarec G, Reichelt M, et al. 2016. Leafmining by Phyllonorycter blancardella reprograms the host-leaf transcriptome to modulate phytohormones associated with nutrient mobilization and plant defense. Journal of Insect Physiology. 84:114-27

146. Zhang H, Guiguet A, Dubreuil G, Kisiala A, Andreas P, et al. 2017. Dynamics and origin of cytokinins involved in plant manipulation by a leaf-mining insect. Insect Science. 24:1065-78

147. Zhao C, Escalante LN, Chen H, Benatti TR, Qu J, et al. 2015. A massive expansion of effector genes underlies gall-formation in the wheat pest Mayetiola destructor. Current Biology. 25:613-20

148. Zhao J, Li L, Liu Q, Liu P, Li S, et al. 2019. A MIF-like effector suppresses plant immunity and facilitates nematode parasitism by interacting with plant annexins. Journal of Experimental Botany. 70:5943-58

149. Zhu L, Chen M-S, Liu X. 2011. Changes in phytohormones and fatty acids in wheat and rice seedlings in response to Hessian fly (Diptera: Cecidomyiidae) infestation. Journal of Economic Entomology. 104:1384-92

150. Zhu L, Liu X, Liu X, Jeannotte R, Reese JC, et al. 2008. Hessian fly ( Mayetiola destructor ) attack causes a dramatic shift in carbon and nitrogen metabolism in wheat. Molecular Plant-Microbe Interactions. 21:70-78 


\section{FIGURES}
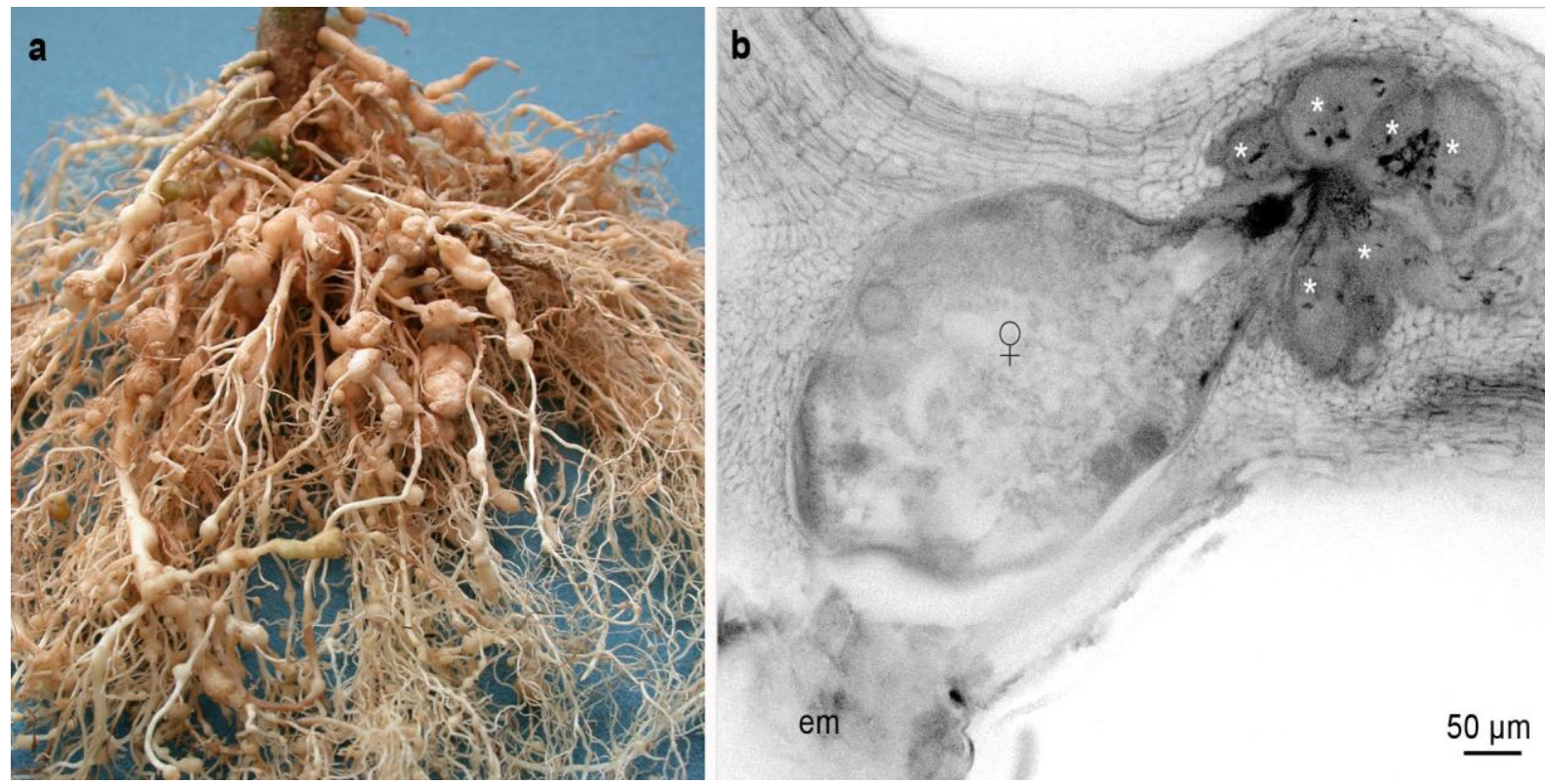

Figure 1 Root-knot nematodes induce the formation of specialized feeding cells. (a) Galls induced by Meloidogyne incognita on tomato (Solanum lycopersicum) roots. (b) Adult female of M. incognita feeds on hypertrophied and multinucleate giant cells and lays eggs into gelatinous egg masses. 

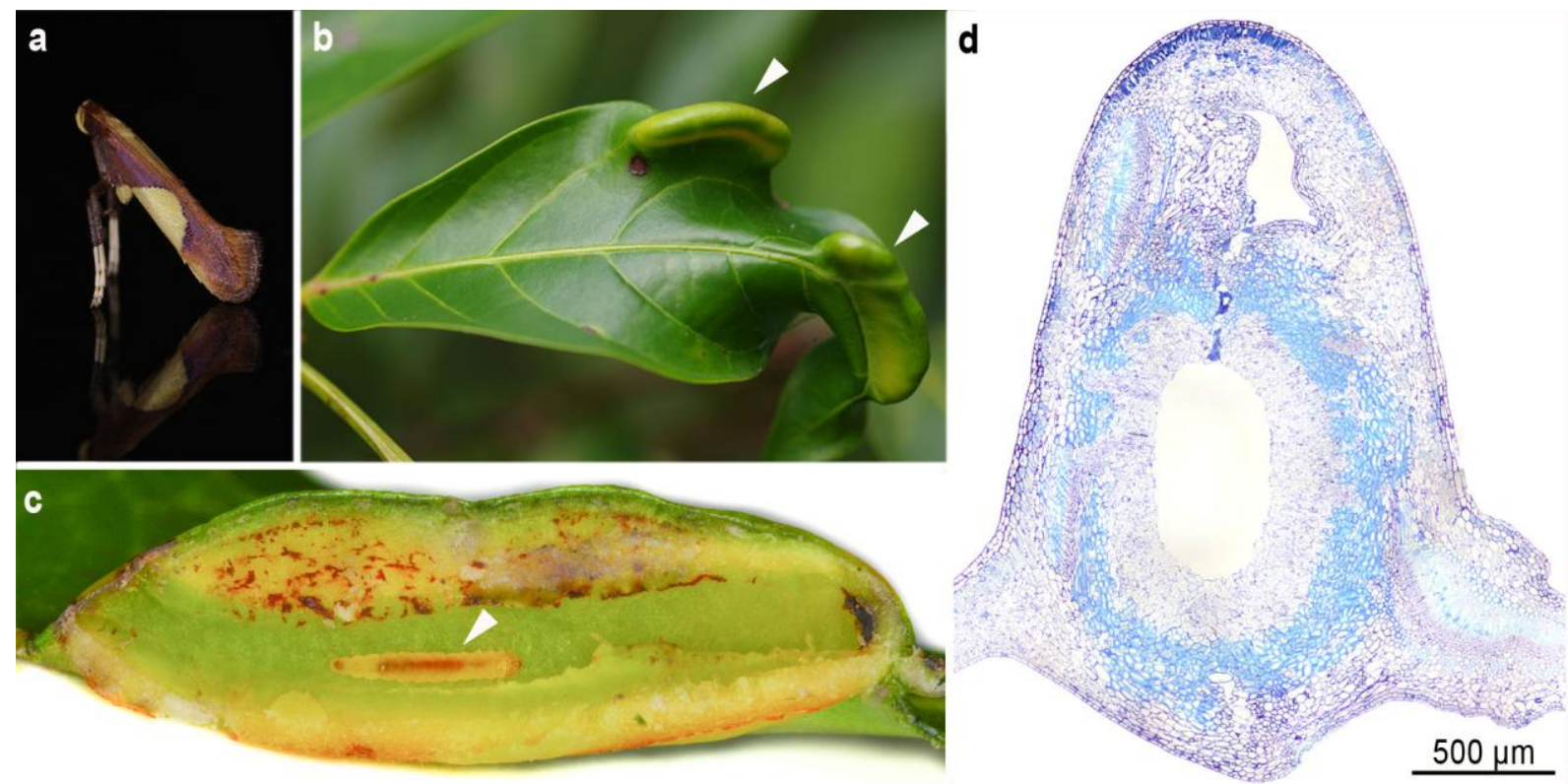

Figure 2 Gall-inducing and leaf miner Lepidoptera Caloptilia cecidophora induces the formation of galls on the leaf of Glochidion plant species (Phyllanthaceae). (a) Adult stage of $C$. cecidophora. (b) Leaf galls (arrowhead) along the vein. All the larval development takes place inside the gall. (c) During the gall initiation process, the larvae first make a leaf mine (arrowhead) before inducing the gall. (d) Histological cross section of Glochidion obovatum leaves attacked by $C$. cecidophora 12 days posthatching. In the mature gall induced, the insect chamber (white inner space) is lined with two kinds of tissues resulting from cell hypertrophy and hyperplasia. The larval chamber is lined by a thin layer of neovascularized nutritive tissue (pink), the development of which from parenchyma is stimulated by larval feeding. At the end of larval development and before pupation, the nutritive tissue is entirely eaten. It is surrounded by sclerenchyma (blue), which confers. Staining: Toluidine Blue O. 